\title{
Układanie niebka. Rola opisu w mojej twórczości prozatorskiej
}

Brygida Helbig-Mischewski

ORCID: 0000-0003-1226-2983

Zacznę od jednego z opisów zaczerpniętych z mojej powieści rodzinnej Niebko:

Podwórko. Godzinami bawiła się z dziećmi na dworze; łazili wokół bloków, zbierali szkiełka spod kiosków i śmietników, bo tam leżało najwięcej butelek porozrzucanych przez pijaków. Zbierali porozrzucane, kolorowe papierki od cukierków, listki. I robili z nich tak zwane niebka. Skąd się wzięła ta zabawa, nie wiadomo. Wykopywali dołki, układali w nich śliczne wzorki ze złotek, sreberek, znalezionych kwiatków i traw, przykrywali szkiełkiem, zasypywali. Trzeba było dokładnie zapamiętać topografię miejsca, wiedzieć, gdzie ukryło się skarb ${ }^{1}$.

Dlaczego narratorka tak lubiła zabawę w „niebko”? Dlaczego tak właśnie zatytułowałam swoją powieść o ludziach wysiedlonych i wykorzenionych, opartą na biografii moich rodziców i dziadków, a także o moim własnym dzieciństwie? Może dlatego, że zabawa w niebko to zatrzymanie się, pochylenie się nad czymś, uklęknięcie. Ziemia styka się w tej zabawie metaforycznie z niebem. Bawiąc się w niebko, drążymy w głąb, w głębi zakopujemy skarb, do którego potem wracamy, który potem na nowo odkrywamy, którego strzeżemy. Dla mnie odkrywaniem, a zarazem stwarzaniem takich skarbów, drobnych klejnotów egzystencji, jest w literaturze właśnie opis. Jest on też sposobem spajania tego, co materialne, z tym, co duchowe.

\footnotetext{
${ }^{1}$ Brygida Helbig, Niebko (Warszawa: Wydawnictwo WAB, 2013), 284.
} 
Od kiedy zaczęłam pisać, faworyzowałam w swoich tekstach właśnie opis - niezależnie od tego, czy były to wypracowania domowe z języka polskiego, czy też pierwsze opowiadania. Twórczość literacką zaczęłam jako małe dziecko od wierszy, od opisywania w nich stanów duszy (których punktem wyjścia były konkretne wydarzenia), ot, chociażby takich, jak ten: „Dziś wyjeżdżamy do NRD/ ach, jaka radość, jak śmiać się chce!”. Albo później, już jako czternastolatka: „Błyszczą w słońcu drobne fale, w złotym słońcu trzcina lśni, patrzę w błękit, coraz dalej, na jezioro marzeń mych". Były to stany radości, poczucia jedności z naturą, błogości, tęsknoty metafizycznej, pragnienia bliskości. Wiersze, zwłaszcza te bardzo opisowe, pisywałam w pięknych miejscach, rozkoszując się tym wyjątkowym stanem ducha wywołanym byciem właśnie tam. Stan ducha domagał się wyrazu, przedłużenia, pogłębienia, delektowania się nim, chwytałam więc za kartkę i długopis, a właściwie zawsze miałam je przy sobie. Czułam, że niecodzienna przestrzeń umożliwi mi szczególne formy przeżycia i opisu. Najlepsze miejsce było zawsze takie, gdzie znajdowała się woda, na której odbijało się niebo, po której powierzchni tańczyły promienie słoneczne, a która jednocześnie uwodziła głębią.

Drugą po „wierszowaniu” podstawową pisarską szkołą było dla mnie pisanie dziennika od trzynastego roku życia. Był on sposobem na zatrzymanie się, wyciszenie, praktykę uważności (chociaż takiego określenia, rzecz jasna, jeszcze nie znałam), pogłębienie życia, na wejście we własną, nierządzoną przez nikogo poza mną przestrzeń absolutnej wolności. Dlatego też wymyśliłam nawet wtedy własny alfabet, żeby nikt poza mną nie miał do tego intymnego świata dostępu, chciałam go chronić przed ingerencją obcego. Miał też mój dzienniczek znaczenie rytualne, pozwalał mi wciąż na nowo rozpoczynać „nowe życie” i opisywać jego jakość. Dawał możliwość odradzania się na nowo, oczyszczenia, był rodzajem nawiązywania dialogu z tym, co nazwalibyśmy dzisiaj w kręgach duchowych wyższym ja, uniwersum, Bogiem, a więc rodzajem modlitwy. Dzisiaj tego rodzaju praktyki są dosyć popularne, w Niemczech niezwykle modne jest pisanie terapeutyczne od lat 70., w Polsce jednak nie mówiło się o tym wiele, byłam zresztą zbyt młoda, aby spojrzeć na to z metaperspektywy, była to czynność czysto intuicyjna, niejako naturalna potrzeba.

Moją główną lekturą w tym czasie była Ania z Zielonego Wzgórza. W powieści tej wydarzenia też miały dla mnie jakby charakter drugorzędny, na pierwszym miejscu stały opisy miejsc ważnych dla bohaterki, zwłaszcza jej pokoiku na poddaszu Zielonego Wzgórza, jej ulubionego drzewa pod oknem, Jeziora Lśniących Wód, a przede wszystkim tego, co działo się w jej głowie, opisy jej stosunku do życia, tworów jej słynnej bujnej wyobraźni. Zakotwiczały się one coraz mocniej w mej psychice, stawały się częścią mojego wewnętrznego, a z czasem i zewnętrznego krajobrazu. Czytałam Anię zawsze z namaszczeniem, zwykle siedząc na parapecie okna swojego minipokoiku, wpatrując się w zachody słońca lub ukochaną topolę, którą za Anią nazwałam „Królową Śniegu”. Czytałam bardzo powoli i, co ważne, wielokrotnie. Wszystkie siedem tomów przeczytałam na pewno kilkadziesiąt razy. Nic już wtedy nie mogło mnie zaskoczyć w tych powieściach, zwroty akcji nie były dla mnie interesujące. Uszczęśliwiające było coraz głębsze wnikanie w świat powieściowy, bo na to właśnie pozwalała wielokrotna lektura i delektowanie się opisami życia wewnętrznego niekonwencjonalnej, twórczej bohaterki. W podobny sposób odbierałam Małą księżniczkę i Tajemniczy ogród Frances Hodgson Burnett.

Niektóre z moich koleżanek czytały w tym czasie Przygody Tomka Sawyera czy Winnetou, ja nie miałam wtedy jakoś do tych książek serca, nie sięgałam po nie. Nie interesowały mnie książki 
przygodowe, nie kręciła mnie akcja pełna napięcia, wręcz przeciwnie, odstręczała mnie nawet, zwłaszcza gdy brakowało w fabule przystanków sprzyjających refleksji, gdy za dużo i za szybko się w nich „działo”. Mimo tego typu obiekcji zachęcona przez koleżankę przeczytałam jako nastolatka jeszcze Trzech muszkieterów, nawet Ogniem i mieczem, ale nigdy do tych książek nie wracałam. Natomiast Ania była dla mnie rodzajem Biblii. Lubiłam jej liryczność, głębię, spokój, nieco paraboliczny charakter. Nie interesował mnie pęd, ruch do przodu na linii horyzontalnej, pragnęłam ciągłego zatrzymywania się i drążenia w głąb, powtarzania w kółko tego samego, wtapiania się w czas mityczny, zgłębiania uniwersalnych prawd.

Moją ulubioną lekturą szkolną było Nad Niemnem Elizy Orzeszkowej, znane właśnie z opisów, przed którymi tak mocno wzbraniali się inni uczniowie. Ja je kochałam, chociaż opisy natury, jeśli były pozbawione elementu psychologicznego, a stawały się celem samym w sobie (bo takie chyba nawet i Orzeszkowej się zdarzały) nudziły także i mnie. Zwykle jednak opis natury splatał się, współgrał, z opisem dusz bohaterek. Takie opisy sprawiały, że ogarniała mnie głęboka błogość. Potem, już jako studentka, pokochałam Siekierezadę Edwarda Stachury, jej śpiewność, refleksyjność, melancholię, a jeszcze bardziej Sklepy cynamonowe Brunona Schulza i to, jak z biograficznych wspomnień potrafił stworzyć pełne sugestywności obrazy o głębokim wymiarze psychologicznym - symboliczną autobiografię. Schulzowskie obrazy, stany, wchodzące w obszar fantastyki, mitu, kolektywnej podświadomości, stały się wieczną inspiracją.

Pełne wielkich szaf, głębokich kanap, bladych luster i tendetnych palm sztucznych, mieszkanie nasze coraz bardziej popadało w stan zaniedbania wskutek opieszałości matki, przesiadującej w sklepie, i niedbalstwa smukłonogiej Adeli, która nie nadzorowana przez nikogo, spędzała dnie przed lustrami na rozwlekłej toalecie, zostawiając wszędzie jej ślady w postaci wyczesanych włosów, grzebieni, porzuconych pantofelków i gorsetów² ${ }^{2}$

Przyznam, że moje własne opisy we wczesnych dziennikach i pierwszych prozatorskich próbach były niepomiernie kiczowate i prawdopodobnie nieopisanie nudne. Na przykład powieść Łzy, której akcja rozgrywała się na cmentarzu. Zostawiłam ją w pawlaczu swojego pokoiku, wyjeżdżając do Niemiec, a rodzice potem ją wyrzucili. Nigdy też nie wygrałam w szkole podstawowej olimpiady polonistycznej, chociaż startowałam, gdyż pani od polskiego lubiła moje pełne patosu wypracowania. Jednak w pracach olimpijskich, a przynajmniej tej jednej z nich, którą pamiętam, nudziłam poetyckimi opisami dziewcząt wyglądających godzinami przez okno, żyjących w swoim hermetycznym świecie, do którego i ja sama tak chętnie z różnych przyczyn uciekałam. Było to trochę tak, jakbym nie miała doświadczenia w zdobywaniu, „podbijaniu" świata zewnętrznego, jakbym nie miała dostępu do akcji, fabuły, napięcia. Niewykluczone, że nie miałam zbyt wiele poczucia sprawczości, mogło to być skutkiem autorytarnego wychowania. W moim dzieciństwie nie było miejsca na własną wolę, którą można by poruszyć świat, na przygodę. Widzę tu sporą zależność między pisaniem a życiem...

Do dzisiaj zresztą trudno mi budować opowiadania czy powieści oparte na pełnej zaskakujących wydarzeń fabule, na przykład na schemacie podróży bohatera. Jedynym chyba opowiadaniem zbliżonym do literackiego reportażu, które zbudowałam, świadomie opierając się na tym schemacie,

\footnotetext{
${ }^{2}$ Bruno Schulz, Sklepy cynamonowe (Wrocław: Zakład Narodowy im. Ossolińskich, 1989), 13.
} 
jest Steinfels - teren prywatny ${ }^{3}$, to jakby posłowie do Niebka. Opisuję w nim perypetie związane z szukaniem w Bieszczadach grobu mojego dziadka Johanna, Niemca galicyjskiego. Jest ono rodzajem powieści drogi i właśnie podróży bohatera, choć trochę z przymrużeniem oka. Bohaterka rusza starą skodą z Berlina w bieszczadzkie chaszcze w podróż do własnych korzeni, wychodzi więc ze stanu bierności, przełamuje swoją codzienną postawę wobec rzeczywistości, konkretnie: odmawia udziału w niej. Stąd też to opowiadanie wydaje mi się istotne. Narratorka wyrusza gdzieś z misją i to jest duża rzecz. Mniej w nim opisów, więcej żywiołu opowieści. Bo opis niesie też ze sobą niebezpieczeństwo nudy i zastoju. W Steinfels opis, gdy się pojawia, służy, bardziej niż w innych moich utworach, rozbudzeniu ciekawości, a nawet wytworzeniu napięcia, przygotowaniu akcji:

Do granicy ukraińskiej jest stąd kilka kilometrów. Polacy jeżdżą tam codziennie na handel, przywożą ukraińskie piwo, którym znieczulają mieszkańców domu starców po polskiej stronie. A Ukraińcy przyjeżdżają do Krościenka, sprzedają pod Biedronką swój alkohol i cukierki. Ale poza tym u nas tutaj spokój. Krążą czasem przy granicy helikoptery, ostatnio było słychać jakieś strzały, ale tu nigdy jeszcze nic się nie stało! ${ }^{4}$

Wrócę jednak do mojej wczesnej profesjonalnej już twórczości. Moja pierwsza, poetycka powieść inicjacyjna Pałówa ${ }^{5}$ była niezwykle opisowa i bazowała w dużej mierze na wspomnianych już, autentycznych dziennikach nastolatki. Opisy i tutaj, jak w samych dziennikach, miewają znaczenie bardzo symboliczne, nawiązują do przestrzeni mitycznych, odkrywają przed czytelnikiem przestrzeń wewnętrzną bohaterki. Pierwsza scena Pałówy to opis zabłąkania bohaterki w wielkich oparach, krajobraz duszy jest mocno oniryczny:

Powolutku, kołysząc biodrami, schodziła schodek po schodku po zakurzonych stopniach swego domu, szła wyżłobionym korytem wyschłej rzeki, był to ogromny, szeroki wąwóz usłany kolorowymi liśćmi, były zimne i mokre, były jesienne i przeorane deszczem, szła z głową wtuloną w szal, do pleców, do szyi przylgnlął jej gorący szal, wiatr bił ją po twarzy, stawiała powolutku krok po kroku, kroki słały się po liściach, ścieliły się po liściach, stawiała więc tak krok za rokiem i za rokiem krok, bardzo rytmicznie i stanowczo, za nią ciągnął się jak blady welon gęsty ogon parującej mgły ${ }^{6}$.

Ostatnia scena Pałówy to symboliczny opis odrodzenia się na nowo - przywołanie wspomnienia komunii świętej i zapowiedź obcięcia włosów:

Anna Maria stała na balkonie i nie widział jej nawet ksiądz. Anna Maria patrzyła na dziewczynkę, powolutku i nieśmiało podchodzącą do ołtarza, klękającą z wahaniem u hostii świętej stóp. Anna Maria wylewała gorzkie łzy. Łzy powrotu i pożegnania. [...] Stała więc oto jak panna młoda, na tym zielonym, na tym wzgórzu, wtulona w ramiona oblubieńca - wiatru, czasu... To stała, to klęczała, to w wodę patrzyła. A kiedy zawirował wokół pył i kurz, zrozumiała, że jej włosy całkiem są porwane, zniszczone i matowe. Pójdę jutro do fryzjera. Dam sobie obciąć włosy. Pomyślała. A ponieważ rozpłynęło się wszystko, Anna Maria wymyśliła się od nowa. Wymyśliła się po prostu jeszcze raz.

\footnotetext{
${ }^{3}$ Brygida Helbig, „Steinfels - teren prywatny”, Tygiel Kultury nr 1-6 (2015): 169-180.

${ }^{4}$ Helbig, 171.

${ }^{5}$ Brygida Helbig, Pałówa (Gdańsk: Wydawnictwo „b 1”, 2000).

${ }^{6}$ Helbig, 10 .
} 
Mam wrażenie, że pisanie było dla mnie rodzajem czynności performatywnej, magicznej, stwarzania czegoś w sobie, jakiejś wewnętrznej rzeczywistości. Jednym z najistotniejszych narzędzi tego kreowania siebie przez pisanie był właśnie opis.

Przez dłuższy czas trudno mi było - opisując - ucieć od kiczu. Już w Pałówie zaczęłam przełamywać go groteską. To chyba lektura Gombrowicza, potem gdańskiego „Totartu” i artystów z kręgu berlińskich „Nieudaczników” wyzwoliła mnie ze szpon płytkiego sentymentalizmu i banału. Zaczęłam przymierzać się do opowiadania fabuły, konstruowania akcji, choćby w charakterze alibi, ale warunkiem zgody na takie zabiegi stały się dla mnie groteskowość i satyryczność tekstu. O ile poprzednio faworyzowałam opis, o tyle teraz dominantą mojej prozy stało się groteskowe zniekształcanie wydarzeń i tworzenie swego rodzaju „antyfabuł”. Jest tak w Aniołach $i$ świniach $w$ Berlinie ${ }^{7}$. Jest tak w Enerdowcach $i$ innych ludziach ${ }^{8}$. Ale i tam nie buduję specjalnie napięcia. Ustawiam raczej obok siebie satyryczne obrazki rodzajowe z pointą. Nie składają się one już tylko z opisów statycznych, jest w nich sporo dynamiki, żywiołu opowiadania. Ale nigdy nie na poważnie. Jakby każda akcja była dla mnie jedynie rodzajem teatru lalek, a najważniejsze było to, co te lalki reprezentują. Aby uniknąć opisowej „nudy”, nauczyłam się oprócz satyryczności także silnej metaforyzacji, gier językowych, rytmizacji.

Jeszcze kilka słów o Enerdowcach $i$ innych ludziach. Ta książka prozatorska zawiera między innymi opowiadania psychologiczne Lieber Rainer i Kallemalle, w których próbuję zgłębić psychikę byłych „Enerdowców”, ich frustrację po zjednoczeniu Niemiec, także ich wzajemne relacje partnerskie naznaczone rozlicznymi traumami. Wiele tam rozbudowanych opisów życia wewnętrznego postaci, które dynamizuję często przy użyciu mowy pozornie zależnej. To dla mnie także ważny środek stylistyczny służący „ożywieniu” opisu:

Uta miała już własne mieszkanie, nienawidziła swojej matki przedszkolanki, całe życie usługującej i ustępującej mężowi lekarzowi, rozjeżdżającemu się z kochankami na konferencje, w wolnych chwilach tresującemu Utę, zawsze niezadowolonemu z jej osiągnięć. Uta trwała w stanie nieustającej rebelii wobec tej starej kobiety. Nigdy nie będzie taką jak ona. Bezwładną i zgorzkniałą. Po śmierci męża złorzeczy tylko na świat. Wiecznie chora, rozgrymaszona, nie bierze odpowiedzialności za własne życie, stęka, jęczy, marudzi, niech sobie idzie, dokąd chce, robi, co chce, niech spada ${ }^{9}$.

Nie pozwalała mu chodzić wieczorami do pomału znikających z krajobrazu knajp narożnych na parówki i mielone, jeździć z Dieterem i Uwikiem do Saksońskiej Szwajcarii jak za dawnych lat, aby tam, z finką pod pachą, nocować w wyłomie skały i, rżnąc dowcip za dowcipem, czuć się prawdziwym mężczyzną. Nie pozwalała mu oglądać się za kobietami, a przecież co Rainer za to mógł, że przyciągały go jak magnes ich talie, biusty i pośladki. Na przykład te Turczynki, co się pojawiły na ulicach. Tylko ich mężów Rainer by przepędził ${ }^{10}$.

\footnotetext{
${ }^{7}$ Brygida Helbig, Anioły i świnie w Berlinie (Szczecin: Wydawnictwo Forma, 2005).

${ }^{8}$ Brygida Helbig, Enerdowce i inne ludzie (Szczecin: Wydawnictwo Forma, 2011).

${ }^{9}$ Helbig, 13.

${ }^{10}$ Helbig, 14.
} 
Jest też jednak w Enerdowcach i opowiadanie typowo liryczne, składające się z prawie samego opisu - Meksykańska dziewczyna. „Enerdowców” już praktycznie tam nie ma, to opowiadanie o życiu wewnętrznym pierwszoosobowej narratorki, czysto obrazowe, intymne, sugerujące autobiografizm. Jego akcja, jeśli o akcji można mówić w tekście będącym jednym wielkim opisem stanu duszy, toczy się w Międzyzdrojach, nad morzem. Otwarta przestrzeń wspiera narratorski projekt spojrzenia w głąb przeszłości i w głąb siebie. Wydarzenia, nawet dialogi, stają się częścią opisu, jakby elementem „zdjęcia” wydobywanego z jakiejś szuflady pamięci albo właśnie robionego przez umysł. Czy taki opis jest statyczny? Nie do końca, bo coś się w nim jednak porusza. Taki opis jest jakby obrazem „ożywionym”. Jest w nim ruch, lecz nie jest to ruch linearny, tylko spiralny raczej, napędzany asocjacjami, skojarzeniami, uczuciami, drgnięciami intuicji:

\begin{abstract}
A jeszcze niedawno sama miałam siedemnaście lat i jadłam w Międzyzdrojach nie kebap berliński, tylko zwykłe placki ziemniaczane. Karmiłam mewy, łabędzie. Rzucałam się z chłopakiem w zimną wodę o północy. Śmiałam się na cały głos. A więc jednak. Kiedyś. [...] Być starą kobietą, to nie jest problem największy. Największy problem, to być rozgoryczoną starą kobietą. [...] Ludzie rozmawiają ze sobą, często jednak nie słyszą się nawzajem. „Ogórki całkiem dobre”, mówi mąż. „Obrus, co obrus?", pyta żona. Coraz mniej na plaży ogórków kiszonych. Moja mama opowiada o swych bólach głowy. Na to moja córka: „Wiesz co, twoje ciało krzyczy”. Mama wybucha śmiechem. Dzielą ich światy, ale potrafią się z tego śmiać. Przechodzą nad przepaścią smugą tęczy. W przepaści zostaję ja ${ }^{11}$.
\end{abstract}

A jak to wygląda w Niebku? Mimo że wiele tam historycznych wydarzeń w tle, to jest ono w sumie także bardzo opisowe. Powieść zaczyna się od opisu. „Willi kolekcjonuje zające wielkanocne" - to pierwsze jej zdanie. Staram się przykuć uwagę czytelnika do intrygującego szczegółu życia codziennego Willego, przestrzeni, w której żyje: „Najbardziej podobają mu się te z firmy Lindt, w złotym złotku, z małym dzwonkiem i czerwoną kokardką na szyi. Nikomu nie pozwoli ich zjeść. Baczność! Wara nam od zajęcy”. Opisuję rzecz i emocjonalny stosunek postaci do tej rzeczy, a to rodzi tajemnicę. Emocja ma być na tyle ciekawa, żeby czytelnik chciał zgłębić jej genezę.

Basia. [...] Wciąż jej się coś przypala. Bo wiecznie goni, ucieka. Wyciąga z szuflady vitaral, żeby ratować chociaż dzieci. To mamy Wunderwaffe - śmieje się Ewa. Niby się śmieje, ale posłusznie łyka podsuwaną jej przez mamę tabletkę za tabletką w krwistoczerwonej polewie, bo po pierwsze, mamie odmówić nie wypada, a po drugie sama już uwierzyła, że będzie bardziej witalna. Marzena też zresztą łyka, jeszcze jak. Aż jej się uszy trzęsą ${ }^{12}$.

Uwagę czytelnika, czytelniczki mają tu przykuć opisywane przedmioty, zając wielkanocny, tabletka vitaral. A budzą one uwagę przez związane z nimi emocje bohaterów - dziwne, niezrozumiałe, intrygujące. Jasne, będzie w Niebku dużo wydarzeń, ale przedstawiam je zwykle w formie opisowej. Wybieram te wydarzenia z życia moich głównych bohaterów Willego i Basi, które były opowiadane narratorce przez rodziców wciąż na nowo, aż stały

\footnotetext{
${ }^{11}$ Helbig, Niebko, 72.

${ }^{12}$ Helbig, 5.
} 
się elementem obrazu w jej głowie. Bardziej więc je opisuję, niż opowiadam, pokazuję, w jaką mozaikę ułożyły się w umyśle narratorki, w jaki stan duszy ją wprawiają, „co z nią robią". Chcę też oczywiście, żeby „zrobiły” coś z czytelnikami, pobudziły do czucia, do myślenia. Chyba przede wszystkim do czucia. Wciąż wracają w Niebku opisy stanów duszy samej narratorki. Nie są one nigdy prostą psychologiczną diagnozą, gdyż operuję przede wszystkim aluzjami, niedopowiedzeniami, przemilczeniami, nawiązaniami, które mają naprowadzić czytelnika na trop transgeneracyjnej traumy, o której transformację i symboliczne uzdrowienie w Niebku chodzi.

Niebko składa się więc prawie wyłącznie z obrazów, chociaż nie ma ich w warstwie graficznej powieści. Moim planem było umieszczenie w książce rysunków lub zdjęć, które podkreśliłyby jej poetycki, a nawet medytacyjny charakter, lecz wydawnictwo nie zgodziło się na to. Za to jak refren wracają w powieści powiedzonka powtarzane przez rodziców, mądrości rodzinne, śpiewane przez przodków piosenki, zastygłe w akustyczny lub wizualny „obraz” w głowie. Przytaczane w kilku miejscach cytaty zatrzymują akcję, która i tak nie jest nastawiona na pęd do przodu. Wszystko jest w Niebku rodzajem „świętego obrazu”, który tworzy, w który wpatruje się narratorka (świętego oczywiście dla niej samej). Nawet więc wydarzenia narratorka prezentuje często poprzez opis, przywoływanie wciąż na nowo innych aspektów tego samego doświadczenia, powtarzanie, pogłębianie, uzupełnianie, dodawanie nowych elementów do kolażu, nowych kwiatków do niebka, nowych barw do kalejdoskopu.

Przy czym często elementy świata zewnętrznego budują metaforyczny most do świata wewnętrznego bohaterów i narratorki. Przytoczę tu opis powojennego Szczecina: „Gruzy na Starym Mieście. Ślady po kulach na murach pięknych kamienic czynszowych, takich jak w Berlinie, tylko o piętro niższych. I mniejsze od strzelania działkami ulicznymi. Cały podziurawiony był ten Szczecin. Podziurawiony Szczecin, podziurawione ludzie i ludziska"13. Dodam jeszcze: i samo Niebko podziurawione. Pełne śladów i pełne dziur, pustych miejsc, milczenia. Jak opisać milczenie? Pewnie robię to, zawieszając jakąś myśl, nie dokańczając jej, usuwając się jako narratorka na bok, w cień, pozwalając „zadziałać” zarysowanemu właśnie, ledwie naszkicowanemu obrazowi.

Bardzo lubię w Niebku rozdział o dzieciństwie narratorki, o jej dziadkach. Próbuję w nim przede wszystkim oddać rytm życia u dziadków, opisać także, jak ten rytm zapisał się w jej w ciele:

Byli wtedy w jej świecie przede wszystkim babka i dziadek. Dziadek Jakub był człowiekiem niezwykłym. Miał piękne, choć już nieco wyblakłe błękitne oczy i potrafił przepowiadać przyszłość. Kochał konie. Huśtał ją wozem zaprzęgniętym w kolejnego swego przyjaciela po rozsłonecznionym miasteczku. Jeździła z nim opromieniona blaskiem, błoga i jakby nieżywa ze szczęścia, pełna mrówek w czubkach palców, z niebem gwałtownie kołyszącym się, otwierającym się w jej głowie. Ze stukotem kopyt końskich w żebrach. Nic piękniejszego nie może sobie wyobrazić, nic bardziej upajającego ${ }^{14}$.

\footnotetext{
${ }^{13}$ Helbig, 235.

${ }^{14}$ Helbig, 269.
} 
Chętnie opieram swoje powieści i opowiadania na wydarzeniach autentycznych, pisząc wciąż nowe „autobiografie”, wciąż nowe „biografie”. Zewnętrzna akcja jest wtedy jakby z góry „dana”, więc nie muszę jej wymyślać (nie lubię tego!), szukam „tylko” jej drugiego, wewnętrznego dna. Zamiast tworzenia pełnego oczekiwania na kolejny zwrot akcji napięcia koncentruję się na wymiarze psychologicznym i metafizycznym wydarzeń. W pewnym momencie dochodzi do tego metaforyka, na pewnym etapie wyłania się ona z tekstu niejako sama, jakby opowieść, dzięki upartemu drążeniu w głąb, nagle znalazła połączenie $\mathrm{z}$ odwiecznymi historiami i obrazami ludzkości, mitami, symbolami, archetypami. A wtedy wszystko zaczyna układać się samo. I mamy „big magic”, o którym, choć może trochę kiczowato, piszą Elisabeth Gilbert czy Julia Cameron ${ }^{15}$.

W powieści Inna od siebie opartej na biografii Marii Komornickiej/Piotra Własta, też, a może nawet jeszcze bardziej, pracowałam kalejdoskopowo, filmowo, zestawiając ze sobą zatrzymane jakby, zastygłe w obraz sceny z życia genialnej pisarki, która w roku 1907 przybrała tożsamość jednego ze swoich przodków, Piotra Własta. Przy czym na obrazy z życia Komornickiej/Własta nakładają się, o czym czytelniczka, czytelnik oczywiście nie wie, obrazy z mojego własnego życia. Właśnie te sceny są moim zdaniem najmocniejsze, podczas pisania których poczułam ich łączność z moją własną biografią, jak na przykład scena, w której ojciec wymierza nastoletniej córce bolesną karę za bunt.

Pewnie, mamy w Innej od siebie akcję, wyraźnie jednak wstrzymywaną, przeplataną opisami spowolnionych jakby działań, ruchów postaci, które oprócz ich oczywistego znaczenia mają drugie, psychologiczne, jedynie zasugerowane (np. metaforą, aluzją lub przemilczeniem) dno.

Powieść zaczyna się od opisu trupa, ubieranego do pogrzebu przez siostry zakonne w suknię. Tym ostatnim obrazem z biografii Własta wprowadzam w sam środek, samo sedno problematyki.

Zwłoki nie protestują. Zwłokom jest wszystko jedno.

- Naprawdę to, siostro?

Siostra Franciszka ma pewne wątpliwości wyciągając z szafy skromne, czarne odzienie, coś w rodzaju szaty, dla sztywnego, kościstego trupa, którego właśnie umyły - chudego, pożałowania godnego. Leży, jak go matka na świat wydała, można by go pokroić i posolić, a on nic. Tym bardziej, że pokawałkowany był już za życia, posolony może jeszcze nie. Jedzony na surowo i bez przypraw. No więc leży i już nie piszczy, nawet marudzić przestał. Trupy są bardzo praktyczne. A tyle jest uprzedzeń wobec nich.

A jeszcze dwa dni temu mówił o sobie Piotr, żądał różnych przywilejów, i same kłopoty z nim były.

Kilka stron poświęcam sarkastycznemu opisowi tej sytuacji, a potem ostatnich miesięcy życia Własta w domu opieki. Opisując jego życie wewnętrzne, posługuję się mocno ironią, 
pojwiającą się zwykle „w pakiecie” z mową pozornie zależną, która, jak już wspomniałam, podkreśla „zapożyczony” charakter obrazu, przetworzonego już niejako przez psychikę narratorki, a więc pelnego niuansów i perspektyw. Przez to staje się on rodzajem „,̇ywego zdjęcia”. Nie to, co się zdarzyło, jest najważniejsze, raczej to, jak tego doświadczają i co dostrzegają w tym bohaterowie, co dostrzega w tym narratorka, co może dostrzec w tym czytelnik, czytelniczka.

Od zarania mojej twórczości literackiej najbardziej fascynowało mnie odkrywanie prawdy, tajemnicy naszego istnienia, docieranie do esencji, do źródła. Pisanie jest dla mnie czynnością na wskroś duchową, polegającą w dużej mierze na wydobywaniu z pamięci, kreowaniu i zgłębianiu „świętych”, czyli kluczowych dla mnie obrazów. W praktyce tej to, co zewnętrzne, łączy się z tym, co wewnętrzne, to, co materialne, z tym, co duchowe. Niebo łączy się z ziemią (jak w niebku), znaczenie metaforyczne z dosłownym, wymiar metafizyczny jest efektem wniknięcia w materię, rzecz, naturę, doświadczenie, ciało, emocje. Tak rozumiane pisanie obrazami, czyli „opisywanie”, umieściłabym umownie w „kobiecym” paradygmacie twórczym, choć oczywiście może on być równie dobrze reprezentowany przez mężczyzn. To jednak nie przypadek, że w naszych patriarchalnych społeczeństwach zwykle to mężczyźni fascynowali się bardziej opowieściami pełnymi przygód, akcji, napięcia niż opowieściami zawierającymi opisy, obrazy. Gdy bawiłyśmy się z koleżankami w układanie niebek na podwórkach, nie było z nami chłopców, a jeśli, to jedynie zmuszeni do tego młodsi bracia. Dzisiaj mężczyźni, i już nie tylko artyści, pomału zaczynają smakować w układaniu niebek, praktykowaniu uważności, kontemplacji. Może to sygnał przełomu czasów. Dostrzegam w tym (trochę chyba utopijną) szansę stworzenia „nowej ziemi”, new earth ${ }^{16}$, o której piszą od jakiegoś czasu współcześni mistycy. To wizja ziemi, na której wartości uznawane dotąd za mniej istotne zostaną dowartościowane, na której yin i yang, prawa i lewa półkula mózgowa, ale także, dodam, opis i opowiadanie, intuicja i intelekt, będą tyle samo warte i traktowane równorzędnie. Bo chyba dotąd jednak nie były.

\footnotetext{
${ }^{16}$ Eckart Tolle, Nowa Ziemia (Konstancin Jeziorna: Wydawnictwo Medium, 2016). Wizję takiego świata moim zdaniem roztaczała w pracach naukowych w swoisty sposób niemal od początku swojej działalności także prof. Maria Janion. Napisałam o tym doktorat: Brygida Miszewski, New-Age-Diskurs in der polnischen Literaturwissenschaft und Lyrik der 70er und 80er Jahre (Monachium: Peter Lang, 1995). Esencję tej dysertacji przedstawiłam w języku polskim w: Brigitta Helbig-Mischewski, „Guru przełomu tysiąclecia. Dyskurs Nowej Ery w pracach Marii Janion”, Teksty Drugie 43/44, nr 1/2 (1977): 165-192, https://tinyurl.com/y4g6epon.
} 


\section{Bibliografia}

Cameron, Julia. Listwan, Jerzy Paweł. Droga artysty: jak wyzwolić $w$ sobie twórcę. Warszawa: Wydawnictwo Szafa, 2017.

Helbig, Brigitta. Anioły i świnie w Berlinie! Fikcja literacka. Szczecin: Wydawnictwo Forma, Księgarnia Autorska, 2005.

Enerdowce i inne ludzie: czyli jak nie zostałem bohaterem. Szczecin: Wydawnictwo Forma, 2011.

Niebko. Warszawa: Wydawnictwo W.A.B. - Grupa Wydawnicza Foksal, 2016. 2000.

Pałówa. Gdańsk: Wydawnictwo b1,

_——. „Steinfels: teren prywatny”. Tygiel Kultury nr 1-6 (2015): 169-180.

Miszewski, Brigitta. New-Age-Diskurs in der polnischen Literaturwissenschaft, Literaturkritik und Lyrik der 70er und 80er Jahre. München: Peter Lang International Academic Publishers, 1995, http://www.oapen.org/download?type= document\&docid=1003824.

Schulz, Bruno. Opowiadania, wybór esejów i listów. Wrocław: Zakład Narodowy im. Ossolińskich, 1989.

Tolle, Eckhart. Nowa Ziemia: przebudzenie świadomości sensu życia. Przetłumaczone przez Wanda Grajkowska. Konstancin-Jeziorna: Wydawnictwo Medium, 2016.

Wielka magia odważ się żyć kreatywnie. Poznań: Dom Wydawniczy Rebis, 2015. 


\title{
SŁOWA KLUCZOWE:
}

\section{o b r a $z$ \\ mistyka}

\author{
opis \\ F A B U E A \\ kreacja \\ gender \\ G $€ E$ E B I A
}

\section{ABSTRAKT:}

Artykuł traktuje o powstawaniu i funkcji opisu we własnej twórczości prozatorskiej autorki, a także o wzajemnym stosunku kategorii opisu i opowiadania. Funkcję i strukturę opisu w swojej prozie autorka porównuje do zabawy dziecięcej w „niebko” (nazywanej także „sekretem"), nawiązując do tytułu jednej ze swoich powieści (Niebko, 2013). Rozpatruje (nie tylko artystyczną, ale i psychologiczną) genezą dominacji opisów w swojej twórczości. Wskazuje na metody, którymi „ożywia” opis w swojej prozie, aby nie był zbyt statyczny i „nudny”. Zastanawia się nad opisem jako narzędziem „pogłębienia” przeżywania egzystencji własnej i czytelnika/czytelniczki, a więc nad jego aspektem mistycznym i terapeutycznym. 


\title{
UWA ŻNOŚć
}

\section{opowiadanie}

\section{metafora}

\author{
S P I R A L A
}

\section{autobiografizm}

\section{NOTA O AUTORZE:}

Brygida Helbig-Mischewski (Brygida Helbig) - pisarka i literaturoznawczyni. Zajmuje się m.in. literaturą migracyjną, polską i niemiecką literaturą współczesną, komunikacją międzykulturową i problematyką gender. Ostatnio wydała powieść Inna od siebie (o Marii Komornickiej/Piotrze Właście, 2017). Postaci tej poświęciła także pracę habilitacyjną Strącona bogini (Kraków 2010), w języku niemieckim Ein Mantel aus Sternenstaub (2005). Jej powieść Niebko znalazła się w finale nagrody NIKE, podobnie jak Enerdowce i inne ludzie. Ukończyła slawistykę i germanistykę na Uniwersytecie w Bochum, pracę doktorską poświęciła głównie prof. Marii Janion, habilitowała się na Uniwersytecie Humboldtów w Berlinie. Redaktorka m.in. tomów Fährmann grenzenlos. Deutsche und Polen im heutigen Europa (z Gabrielą Matuszek, 2008) oraz Migrationserfahrungen im vereinten Europa (z Małgorzatą Zduniak-Wiktorowicz, 2018). Felietonistka radia "Cosmo” w Niemczech, współzałożycielka i członkini Rady Naukowej Uniwersytetu Trzech Pokoleń w Berlinie. Obecnie profesor UAM. Mieszka w Berlinie. 